\title{
THE AFRICA CAFÉ: A CASE STUDY ON THE SUCCESS FACTORS ASSOCIATED WITH SUSTAINABLE ENTREPRENEURSHIP IN SOUTH AFRICA
}

\author{
Steven W. Day, North Carolina Central University, U.S.A.
}

dx.doi.org/10.18374//JBR-20-1.3

\begin{abstract}
This study describes the case study of a Black South African sustainable entrepreneur who formed a new venture in Cape Town after the Apartheid. The purpose of this article is to further investigate entrepreneurial activities in South Africa. It is often presumed that the black population of South Africa has a low participation rate in entrepreneurial activities and a low level of ambitions regarding self-employment. This study examines a case of how the South African Tourism and Hospitality industry cultivated an entrepreneur and a small successful restaurant by the name of Africa Café. Although the founder was a black South African and had to overcome racism and adversity associated with the Apartheid era, he still managed to grow a successful business that continues to expand operation today. This paper presents the accounts of the successful entrepreneur, Mr. Hector Mbay and the strategy he used in developing a sustainable small business in Cape Town, South Africa. The data collection in this study involved administering inductive interviews and analyzing the information after. The interviews were conducted with the owner Mr. Hector Mbay. He was chosen because of his direct and hands on experience with the sustainable development of the Africa Cafe. The examination of this particular individual and his unique business model is essential because it further substantiates previous research undertaken in other contexts and paradigms on the components of sustainable entrepreneurship. The purpose of this paper is to review and extend the current literature by further developing an integrated model of sustainable entrepreneurship.
\end{abstract}

Keywords: sustainable entrepreneurship; innovation management; competitive advantage; value capture, value creation, shared value 